\begin{tabular}{|l|c|c|c|r|}
\hline $\begin{array}{l}\text { Cuadernos de Investigación Geográfica } \\
\text { Geographical Research Letters }\end{array}$ & 2017 & N $^{\circ} 43(1)$ & pp. 101-118 & $\begin{array}{r}\text { ISSN 0211-6820 } \\
\text { eISSN 1697-9540 }\end{array}$ \\
\hline
\end{tabular}

DOI: http://doi.org/10.18172/cig.3131

(C) Universidad de La Rioja

\title{
AN INTERDISCIPLINARY TILLAGE EROSION EXPERIMENT: ESTABLISHING A NEW FIELD IN GRASSLANDS WITH RECONSTRUCTED ARD PLOUGH OF THE BRONZE AGE - IRON AGE
}

\author{
J. PAVELKA ${ }^{1}$, A. SMETANOVÁ ${ }^{2,3^{*}}$, J. REJMAN ${ }^{4}$, P. KOVÁČIK ${ }^{1,5}$ \\ ${ }^{1}$ Institute of Archaeology, Silesian University, Opava, Czech Republic. \\ ${ }^{2}$ Institute of Ecology, Ecohydrology and Landscape Evaluation, Technical University, Berlin, Germany. \\ ${ }^{3}$ INRA, Laboratoire d'Etude des Interactions entre Sol-Agrosystème-Hydrosystème, \\ UMR LISAH, Montpellier, France. \\ ${ }^{4}$ Institute of Agrophysics, Polish Academy of Sciences, Lublin, Poland. \\ ${ }^{5}$ Archaia Olomouc o. p. s., Olomouc, Czech Republic.
}

\begin{abstract}
Despite recognising the role of tillage erosion in landforms evolution, little research has documented its effects in prehistoric times. Herein, an interdisciplinary archaeological-geomorphological experiment with reconstructed tillage tools and management was conducted in order to measure tillage erosion when a new field in grasslands was established in the Bronze Age-Iron Age. Three wooden ards were reconstructed based on archaeological findings. They were tested in a cross-tillage experiment, consisting of a tillage pass perpendicular to the primary slope (6.5-9.7\%), and a second tillage pass parallel to the primary slope of a convex-convex ridge with mowed grass $(0.2$ $m$ high, vegetation cover $>90 \%$ ). The standard sole ard proved to be the most effective, with a mean tillage depth of $\sim 0.12 \mathrm{~m}$, a mean tillage speed of 3.8 $\mathrm{km} \mathrm{h}^{-1}$, and a mean distance between furrows of 0.20-0.25 m. Only 13\% of the 264 tracers placed on 6 transects were displaced, and the mean tracers displacement parallel to the primary slope was $0.04 \pm 0.17 \mathrm{~m}$. Contour tillage perpendicular to primary slope created $V$ or $U$ shaped furrows with a mean depth of 0.1-0.12 m, a mean width of 0.05-0.1 m, and incision under the main root zone. Only soil in direct contact with the ard was displaced, with a mean translocation distance of $0.06 \pm 0.2 \mathrm{~m}$ parallel and $0.06 \pm 0.3 \mathrm{~m}$ perpendicular to the primary slope. During tillage parallel to slope, soil clods of $\sim 0.20 \times 0.25$ $x 0.10 \mathrm{~m}$ were created and slightly disturbed or turned over one another. The tracers moved within the furrows and with the soil clods. Loose soil, resembling a seedbed, was not covered by soil clods. Mean displacement during the second pass was $0.03 \pm 0.19 \mathrm{~m}$ parallel and $0.00 \pm 0.15 \mathrm{~m}$ perpendicular to primary slope. The displacement from cross-tillage with a wooden ard in permanent grasslands was lower than many previously measured values of traditional animal-powered metal ploughs in permanent fields. No relationship between
\end{abstract}


mean soil displacement and slope gradient was found. Dense vegetation and root structure influenced ard soil-penetration, its movement within the soil, and the displacement of tracers packed between the roots. Cross-tillage with a wooden ard proved to be insufficient for seedbed preparation. The results suggest that grazing or fire management, followed by repeated tillage with ard or hoe in order to destroy soil clods were necessary to establish a new field in grasslands during the Bronze Age-Iron Age.

\section{Un experimento interdisciplinar sobre erosión por laboreo: la roturación de praderas con arados reconstruidos de la Edad de Bronce y Hierro}

RESUMEN. A pesar del reconocido papel de la erosión por laboreo en la evolución de las formas del paisaje, las investigaciones que documenten sus efectos en la Prehistoria son escasas. Presentamos un experimento geomorfológico y arqueológico interdisciplinar basado en la reconstrucción de utensilios y técnicas de laboreo de la Edad del Bronce y Hierro con el fin de medir la erosión por laboreo durante la roturación de prados permanentes. Tres arados de madera fueron reconstruidos según hallazgos arqueológicos. La efectividad de los arados fue examinada en un experimento de laboreo cruzado, definido por un trazado perpendicular a la pendiente principal (6.5-9.7\%) y un segundo trazado paralelo a la pendiente principal, en una divisoria con prados (vegetación herbácea de $0.2 \mathrm{~m}$ de altura y una cubierta $>90 \%$ ). El arado estándar fue el más efectivo, con una profundidad de laboreo de $\sim 0.12 \mathrm{~m}$, una velocidad media de $3.8 \mathrm{~km} \mathrm{~h}^{-1}$ y una distancia media entre surcos de 0.20-0.25 m. Solamente el 13\% de los 264 trazadores colocados en 6 transectos fueron desplazados, y el desplazamiento medio paralelo a la pendiente principal fue $0.04 \pm 0.17 \mathrm{~m}$. El laboreo siguiendo las curvas de nivel, perpendicular a la pendiente principal, creó surcos en forma de Vo U con profundidades medias de 0.1-0.12 m, anchuras medias de 0.05-0.1 m, e incisiones por debajo de la zona radicular del suelo. Sólo el suelo en contacto directo con el arado fue desplazado, con una distancia media de desplazamiento de $0.06 \pm 0.2 \mathrm{~m}$ en paralelo y $0.06 \pm 0.3 \mathrm{~m}$ en la perpendicular a la pendiente principal. Durante el laboreo paralelo a la pendiente principal, se crearon terrones de suelo de dimensiones $\sim 0.20 \times 0.25 \times 0.10 \mathrm{~m}$, ligeramente alterados y volcados los unos sobre los otros. Los trazadores se movieron dentro de los surcos y junto con los terrones de suelo. El suelo suelto, a modo de un lecho de siembra, no quedó cubierto por los terrones del suelo. El desplazamiento medio durante el segundo pase fue de $0.03 \pm 0.19 \mathrm{~m}$ en paralelo y $0.00 \pm 0.15 \mathrm{~m}$ en perpendicular a la ladera principal. El desplazamiento debido al laboreo cruzado con arado de madera en prados permanentes fue inferior al medido en estudios previos en campos de cultivo con arados de metal utilizando animales. No se encontró ninguna relación entre el desplazamiento del suelo y la pendiente. La cobertura vegetal y la estructura de las raíces tuvieron influencia en la penetración del arado en el suelo, su movimiento en el suelo y el desplazamiento de los trazadores entre las raíces. El laboreo cruzado con un arado de madera se mostró insuficiente para la preparación de un lecho 
de siembra. En la Edad del Bronce-Hierro, el pastoreo o la utilización del fuego, seguidos de un laboreo recurrente con arado o con azada para destruir los terrones del suelo, tuvieron que ser necesarios para roturar nuevos campos de cultivo en prados permanentes.

Key words: tillage erosion, ard, archaeological experiment, Bronze Age, environmental impact, interdisciplinary approach.

Palabras clave: erosión por laboreo, arado, experimento arqueológico, Edad de Bronce, impacto medioambiental, enfoque interdisciplinar.

Received 1 November 2016 Accepted 30 December 2016

* Corresponding author: Anna Smetanova, Institute of Ecology, Ecohydrology and Landscape Evaluation, Technical University, Berlin, Germany. E-mail address: anna. smetanova@gmail.com

\section{Introduction}

Tillage -the preparation of soil for seeding and crop cultivation- was one of the primary innovations of the Neolithic, leading to great cultural, technological and sociopolitical changes with global consequences (Lemmen et al., 2011). Archaeological findings suggest continual evolution of tillage tools and methods, starting with simple (hypothetical) ploughing with deer horns (Kănčev, 1956), different types of ards and ploughs, and finally modern tillage tools used at present. From a historical perspective, tillage is considered part of the anthropogenic forcing on soils, affecting landscape evolution and societies (Dotterweich et al.,2013). Despite evidence that tillage induced landform evolution in the past (Bac, 1928; Follain et al., 2009; Houben 2008, 2012; Nyssen et al., 2014; Smetanová et al., 2015), little is known about the erosivity of pre-historical and historical tillage tools and tillage management strategies. However, tillage erosion -displacement of the cultivated soil layer in the direction of tillage (i.e., tillage erosion)- has been recognized as an important recent soil degradation process with effects on landscape evolution, soil properties, environmental quality, and consequences to the global carbon cycle (Lindstrom et al., 1992; Govers et al., 1994; Kosmas et al., 2001; Van Oost et al., 2005,2006,2012). Erosivity of tillage operation is closely connected to the characteristics of tillage tools (shape, width, length, etc.) and tillage management strategy (tillage depth, speed, tillage direction; Lobb et al., 1999), and thus differed between recent and pre-historical tillage instruments. Several studies investigated traditional tillage practices (e.g., hoeing and manually-drawn tillage using ards) in developing countries to provide comparison with commonly used agricultural practices (Thapa et al., 1999; Nyssen et al. 2000; Dercon et al. 2007; Barneveld et al., 2009; Dupin et al., 2009; Table 1). Numerous archaeological reconstructions of tillage tools were conducted to test various archaeological hypotheses, e.g. shoe adze (Quente, 1914; Brentjes, 1956; Henning, 1965), ards (Aberg and Bowen, 1960; Hansen, 1969; Semjonov, 1974; Reynolds 1979, 1988; Lüning et al., 1980; Podborský, 


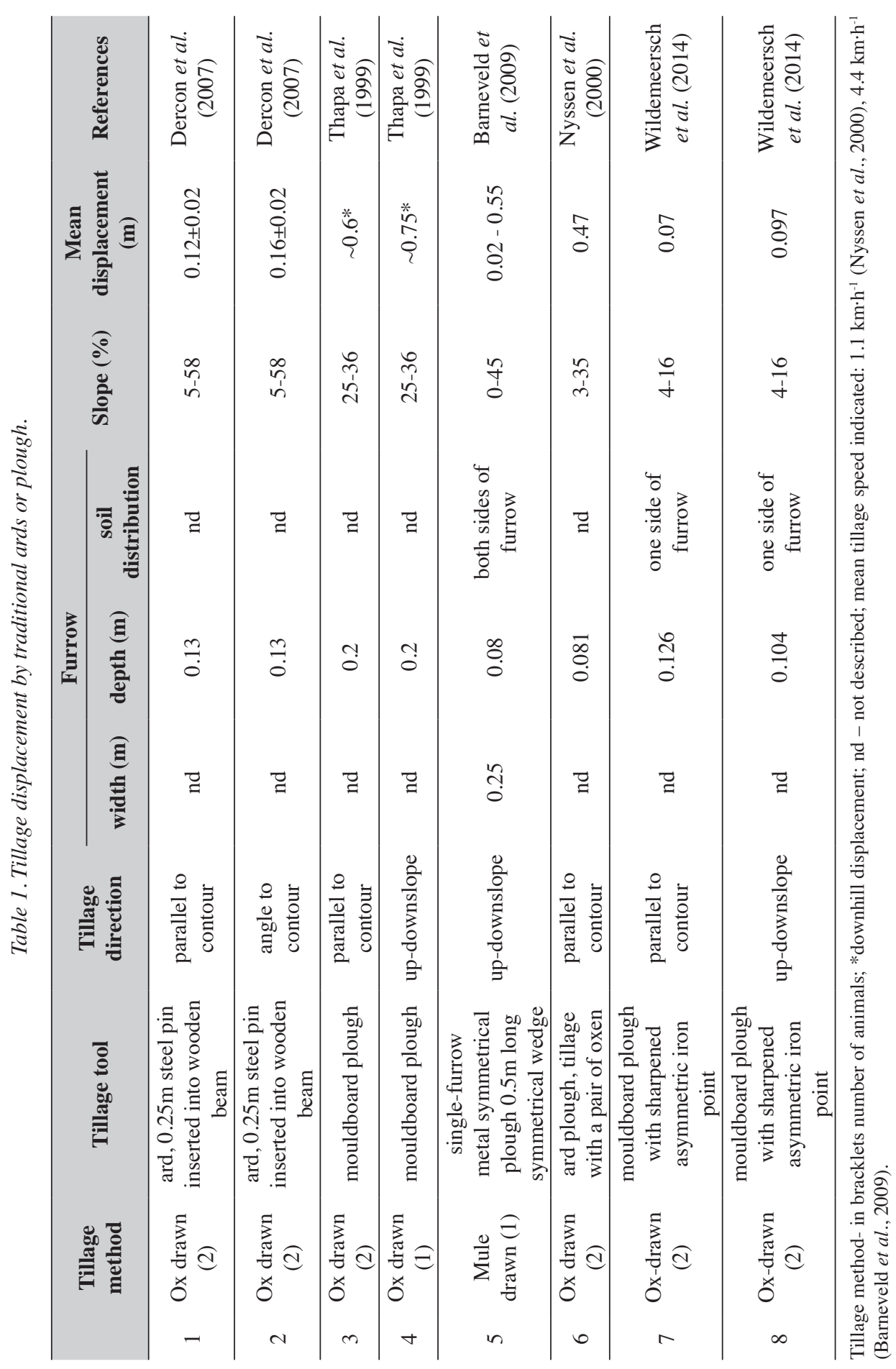


1984; Beranová, 1993; Hejcman et al., 2015), medieval ploughs (Lerche, 1986, 1991, 1994, 2014; Šach, 1966), but none have assessed the erosivity of historical tillage tools. Contrary to the recent application of tillage tools in fields with long-term use, prehistoric tillage tools were more often used to establish new fields in pristine landscapes, or to till pastures and grassland fallows in prehistorical times (Graves, 1960). In this study we use an interdisciplinary archaeological-geomorphological approach in order to (i) assess the usability of ards that were commonly used in Central Europe at the turn of the Bronze Age-Iron Age for setting up new fields in grasslands or tilling a long-term fallow field, and (ii) provide the first evaluation of tillage erosion of a pre-historical tillage tool.

\section{Material and Methods}

The experiment consisted of different phases (Fig. 1). Prior to measuring tillage erosion, tillage tools were reproduced and tillage management was tested by an archaeological experiment. The tillage tools were reconstructed based on archaeological findings of original ards found during the archaeological survey on the site Opavapivovar (part Dolní dvůr, trench G9) in Opava, Czech Republic, and dated by standard radiocarbon methods to 1131-1026 BC (Kováčik et al., 2010; Fig. 2A). Each ard, identical in characteristics, differed from standardized models of European sole ards (Tegtmeier, 1993; Fig. 2G) as follows, (i) the sole, into which the stilt is inserted, was missing, and (ii) the beam ended by oval cut or severed hole for the tie hook (Fig. 2C). These changes indicated ritual storage of ards in water, but practical reasons such as (i) intended storage in water environment in order to increase the volume of the oak wood in water environment, or (ii) winter storage in water environment were not excluded and the usability of tillage tools for tillage operations is unclear.

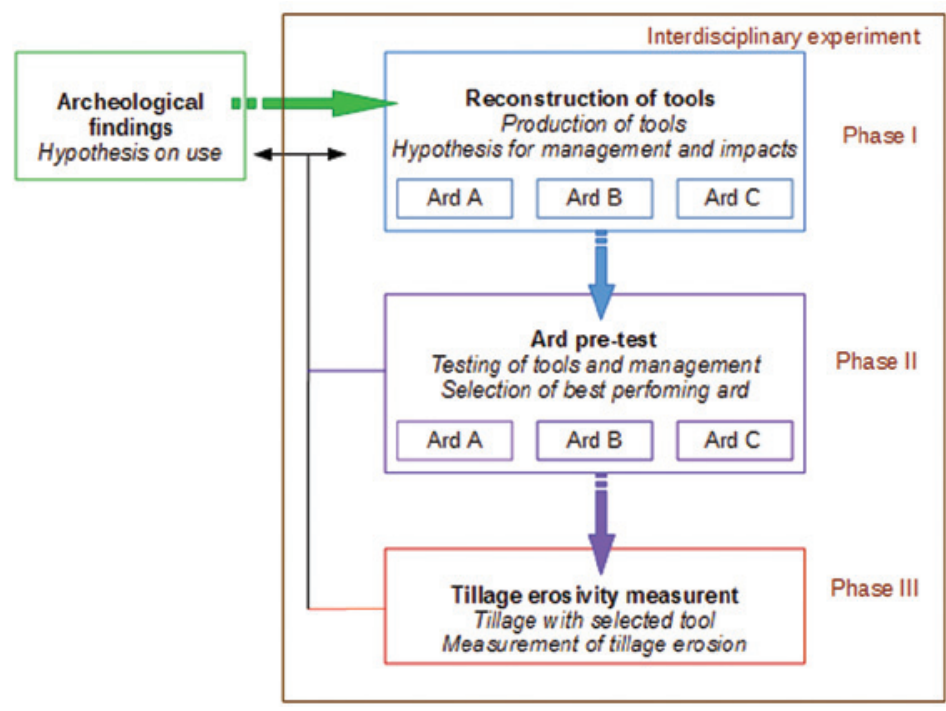

Figure 1. Methodological approach of the interdisciplinary experiment. 

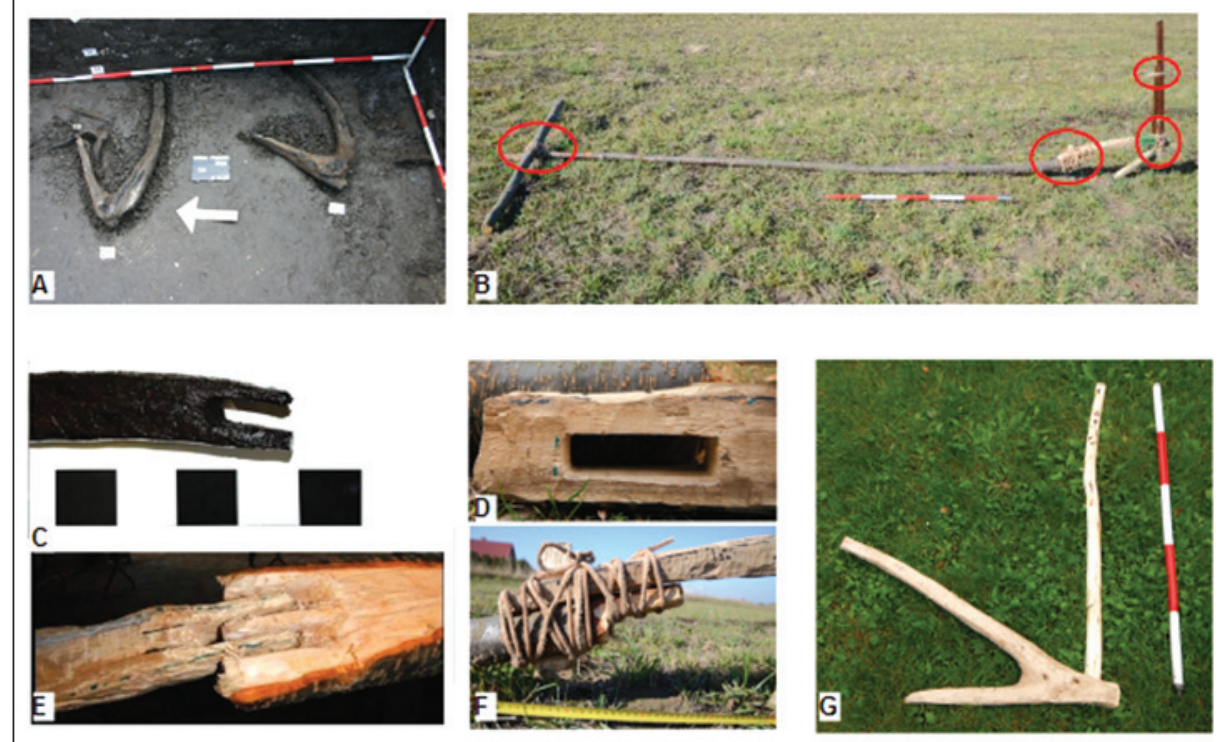

Figure 2. Ards. A: Recovered ards from archaeological digs (1131-1026 BC). B: Reconstructed ard $B$ prepared for ploughing; red circles show joins between parts with leather lines. $C$ : Beam of a recovered ard ending with oval cut. D: Reconstructed hole for a tie hook in ard B. E: Reconstructed ard A.F: The join between ard and beam using leather lines ( $\operatorname{ard} B)$. G: The standardized (ard $C$ ) type with sole and tie hook (Tegtmeier, 1993). Photos: A, Peter Kováčik; B-G, Jan Pavelka.

\subsection{Archaeological reconstruction of tillage tools}

In order to understand if the type of ard found in the archaeological finding was used for tillage, three types of ard were reconstructed. Each represented a unique augmentation of the original finding. First, an exact replica of the archaeological findings with cut sole and beam (furthermore, ard A; Fig. 2E) was prepared. Second, a hypothetical ard was reconstructed with cut sole and a reconstructed hole for the tie hook (ard B; Fig. 2B, 2D, 2E). Finally, the standardized model (Tegtmeier, 1993) of sole ard with a reconstructed hole for the tie hook (ard C) was produced (Fig. 2G). Each ard was constructed using tools common of the Bronze Age (bronze axe, bronze knife, bone chisel and flint flake) from a dried oak wood. The production of each ard primarily differed in how the ard and beam were joined. Each reconstructed ard was attached by the tie hook to the beam produced from alder wood. The total length of the beam with ard $(0.7 \mathrm{~m})$ was $3.4 \mathrm{~m}$, similar to the archaeological findings (Glob, 1951). At the end of the beam, a three-meter yoke from alder (ard B) or birch (ard C) was attached.

\subsection{Experimental plots}

The experimental plots were situated in the Ostravská Pánev Basin, in the cadastral area Dětmarovice (Fig. 3A), which is only $34 \mathrm{~km}$ from the archaeological site Opava- 
pivovar. The landscape is characterised by long ridges with gentle slopes, covered by loess and Planosols (IUSS Working Group WRB, 2015). Two experimental fields in permanent grasslands were used (Fig. 3B), following the archaeological evidence suggesting that historical tillage in Central Europe primarily occurred on flat land, terraces, or shallow slopes (Tegtmeier, 1993).

A square field $\left(10 \mathrm{~m}^{2}\right)$ with an average slope of $\sim 0 \%$ was tilled during the preliminary test (described in section 2.3). For the interdisciplinary tillage erosion measurements, a steeper slope was selected (Fig. 3B). The plots $(3 \times 6 \mathrm{~m})$ were situated on a gentle convex-convex ridge with an average slope of $8 \%$ (Fig. 3C) covered with a mowed grass with natural specimens up to $0.2 \mathrm{~m}$ high and with vegetation cover $>90 \%$. Plots P1, P2 and P3 respectively represent upper-convex slopes, middle-linear slopes, and lower, slightly concave slopes. The plots were divided into two parts (e.g., P1.1, P1.2) in order to differentiate between measurements in two tillage directions (section 2.4).

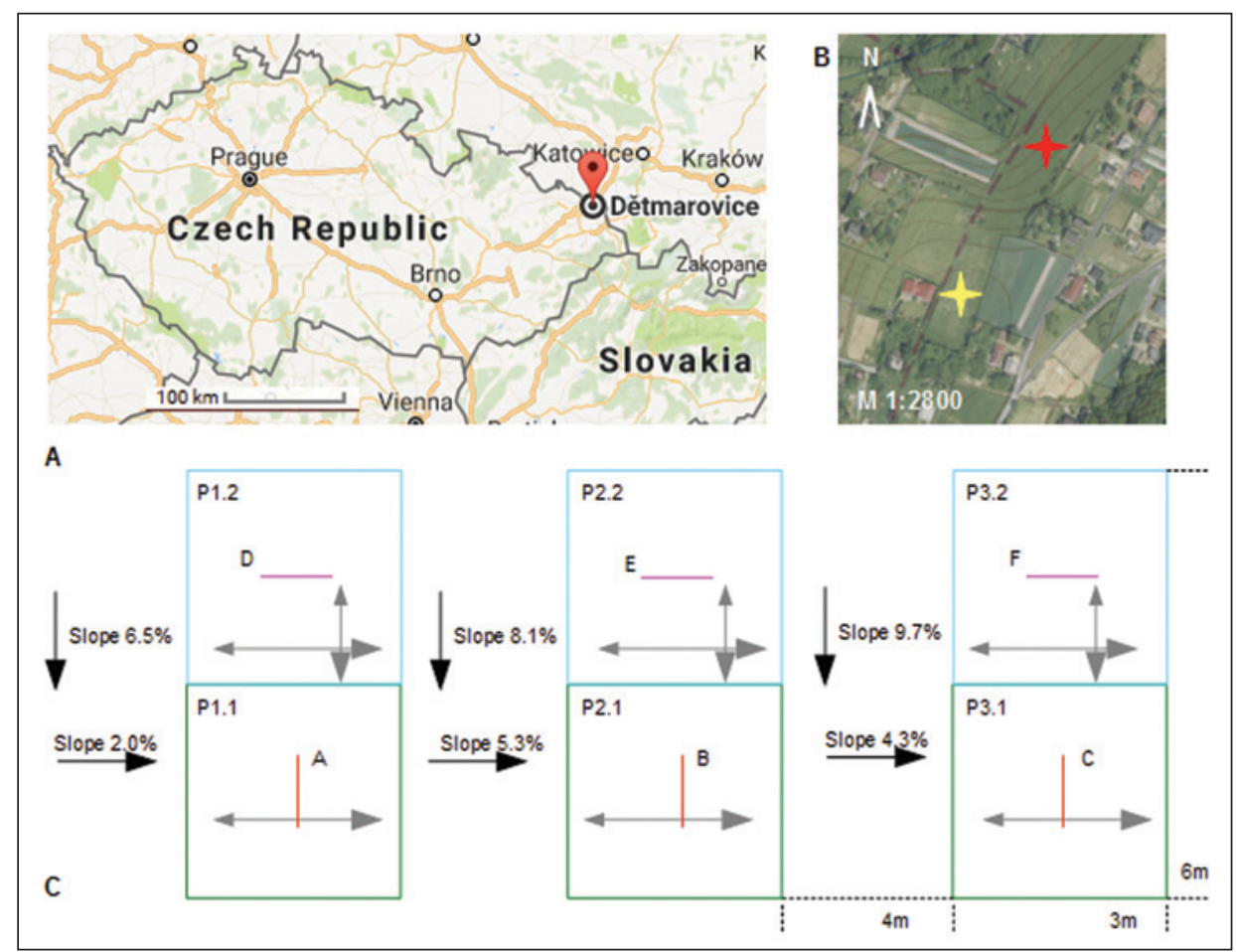

Figure 3. Study site. A: Dětmarovice is situated in the Silesian region. B: Localisation of study sites: the yellow star indicates the ridge-top with slope $0 \%$ used in the archaeological test, the red star indicates the convex-convex slope with slope 2-10\% used in the interdisciplinary experiment $\left(49.88^{\circ} \mathrm{N}, 18.44^{\circ} \mathrm{E}\right)$. C: Experimental plots $\mathrm{P} 1, \mathrm{P} 2, \mathrm{P} 3$ each subdivided into subplots 1 and 2 (e.g., P1.1,P1.2) with different tillage directions (grey arrow). Slopes for fields $P 1, P 2, P 3$ are indicated. Red and purple rows represent tracer transects $A-F$, each consisted of 44 tracers, $0.1 \mathrm{~m}$ apart in four depths $0 \mathrm{~m}, 0.04 \mathrm{~m}$, $0.08 \mathrm{~m}, 0.12 \mathrm{~m}$. 


\subsection{Preliminary tests of reconstructed tools and tillage management}

A preliminary test was performed in order to test the tools' ability (ards A, B, and C) to till and reconstruct historical tillage management. We assume that ploughing permanent grasslands represented Bronze Age-Iron Age method to set up a new field in a grassland area in non-settled landscapes, or in grassland fallow fields in cultural landscapes. By that period, tillage in two directions perpendicular to each other (cross-tillage) was common and oxen were predominantly used to draw ploughs (Huisman et al., 2014; Tegtmeier, 1993; Verril et al., 2010). It was not possible to obtain an oxen trained for tillage of a size comparable with Bronze Age-Iron Age, thus we employed four adultmen (each $\sim 80 \mathrm{~kg}$ ) as an equivalent. The tillage operation was controlled by a ploughman, who maintained consistent tillage depth and distance between furrows. Tillage with ards A and B were performed in autumn of 2015, while ard $\mathrm{C}$ was tested prior to the interdisciplinary experiment in autumn of 2016. The effectiveness, performance, and faultiness of tillage tools were assessed qualitatively during the experiments.

\subsection{Experimental set-up}

Results of the preliminary tests (section 3.1) indicated the most effective and least faulty ard, which was selected for tillage erosion measurements. The tillage management was identical to the preliminary test; only plot sizes differed to allow measurement of tillage in two directions and minimize labour requirements. The tillage erosion measurements were performed by standard tracer methods using aluminium cubes (edge length $1.5 \mathrm{~cm}$ ), each marked by unique combinations of number and colour. Three rows of cubic aluminium tracers placed $0.1 \mathrm{~m}$ apart from each other (covering a total of $1 \mathrm{~m}$ ) at four different depths $(0 \mathrm{~m}, 0.04 \mathrm{~m}, 0.08 \mathrm{~m}$ and $0.12 \mathrm{~m})$ below the surface were used to measure the tillage in each direction (contour and up-down slope). Each tracer transect consisted of 44 aluminium cubes with known x, y, z coordinates (Fig. 3C). Prior to the experiment, the tracers measuring displacement from contour tillage (rows A-C, Fig. 3C) were established, and soil samples were taken for gravimetric soil moisture and bulk density analysis from a soil depth of 0-0.1 m. All plots were tilled with an average furrow distance of 0.2-0.25 m, providing two tillage passes along and opposite to tillage direction for one row of tracers (four total passes). First, contour tillage was performed perpendicular to the primary slope following the convexity of the landforms. During the first and second tillage pass, the speed during up-downslope tillage was measured on three $5 \mathrm{~m}$ transects, and the mean tillage speed calculated. After the contour tillage, three other rows of tracers (D-F, Fig. 3C) were placed into the tilled plots (P1.2, P2.2, P2.3, Fig. 3C) and the soil was sampled again. Second, up-and down slope tillage occurred parallel to primary slope direction. After up-down slope tillage of each plot, all tracers were carefully excavated and their position was measured in a 3-dimensional space using an aluminium frame placed perpendicular to the surface. For each tracer, the displacement was calculated along the primary slope, in the direction perpendicular to the primary slope, and the vertical movement. Negative values were assigned to upslope movement and positive values to downslope movement. 


\section{Results}

\subsection{Suitability of reconstructed ards for tillage}

During the experiment, the exact replica ( $\operatorname{ard} \mathrm{A}$ ) proved to be unsuitable for tillage (Table 2). The second model (ard B) was able to perform tillage, but joins were often destroyed during tillage and required reparation. The third model ( $\operatorname{ard} \mathrm{C}$ ) was selected for the interdisciplinary experiment, as only the yoke was destroyed due to weather conditions several times during the test tillage. It was easily replaced by another similar piece of wood. During the test with ards B and C, the average furrow distance was $0.2-0.25 \mathrm{~m}$. It was not possible to achieve a higher furrow density due to the ards' forward movement in the direction of previously tilled furrows, and subsequently falling into them.

Table 2. Tillage results from each reconstructed ards.

\begin{tabular}{|c|c|c|c|c|c|c|c|}
\hline \multirow{2}{*}{ Ard } & \multicolumn{2}{|c|}{ Experiment } & \multicolumn{3}{|c|}{ Plough row (mean) } & \multirow{2}{*}{$\begin{array}{c}\text { Speed } \\
\left(\mathbf{k m} \cdot \mathbf{h}^{-1}\right)\end{array}$} & \multirow{2}{*}{$\begin{array}{l}\text { Faultiness } \\
\text { during tillage }\end{array}$} \\
\hline & Date & $\begin{array}{l}\text { Weather/Soil } \\
\text { conditions }\end{array}$ & $\begin{array}{l}\text { Depth } \\
\text { (m) }\end{array}$ & $\begin{array}{l}\text { Width } \\
\text { (m) }\end{array}$ & $\begin{array}{l}\text { Distance } \\
\text { (m) }\end{array}$ & & \\
\hline Type A & $05 / 10 / 2015$ & sunny / dry & $0.02-0.03$ & $0.04-0.05$ & $\mathrm{~nm}$ & $\mathrm{~nm}$ & extreme \\
\hline Type B & $24 / 10 / 2015$ & sunny / dry & $0.80-0.12$ & $0.05-0.06$ & $0.20-0.25$ & 4.3 & $\begin{array}{l}\text { medium, the } \\
\text { joins loosened } \\
\text { more times, } \\
\text { yoke broke } \\
\text { once }\end{array}$ \\
\hline Type C & $19 / 09 / 2016$ & cloudy / wet & $0.10-0.12$ & $0.05-0.10$ & $0.20-0.25$ & 3.8 & $\begin{array}{l}\text { medium, only } \\
\text { yoke broke } \\
\text { several times } \\
\text { during tillage } \\
\text { due to wet } \\
\text { conditions }\end{array}$ \\
\hline
\end{tabular}

nm- not measured.

\subsection{Tillage erosion}

Tillage was performed at an average speed of $3.8 \mathrm{~km} \mathrm{~h}^{-1}$, with average depth of $\sim 0.12 \mathrm{~m}$ and distance between furrows of $0.20-0.25 \mathrm{~m}$. Before the first tillage, the bulk density in the upper $0.1 \mathrm{~m}$ of soil was $574 \mathrm{~kg} \mathrm{~m}^{-3}$ and gravimetric water content was $29 \%$. After contour tillage, the bulk density increased by $\sim 30 \mathrm{~kg} \mathrm{~m}^{-3}$ while the water content remained similar (26\%). Only $13 \%$ of the tracers were translocated and no single tracer was moved at the depth $-0.12 \mathrm{~m}$. There was a high variability in transport distances of displaced tracers (Table 3 ). The mean displacement along the primary slope direction of all tracers at depths between $0-0.08 \mathrm{~m}$ was $0.04 \pm 0.17 \mathrm{~m}$. No significant correlation 


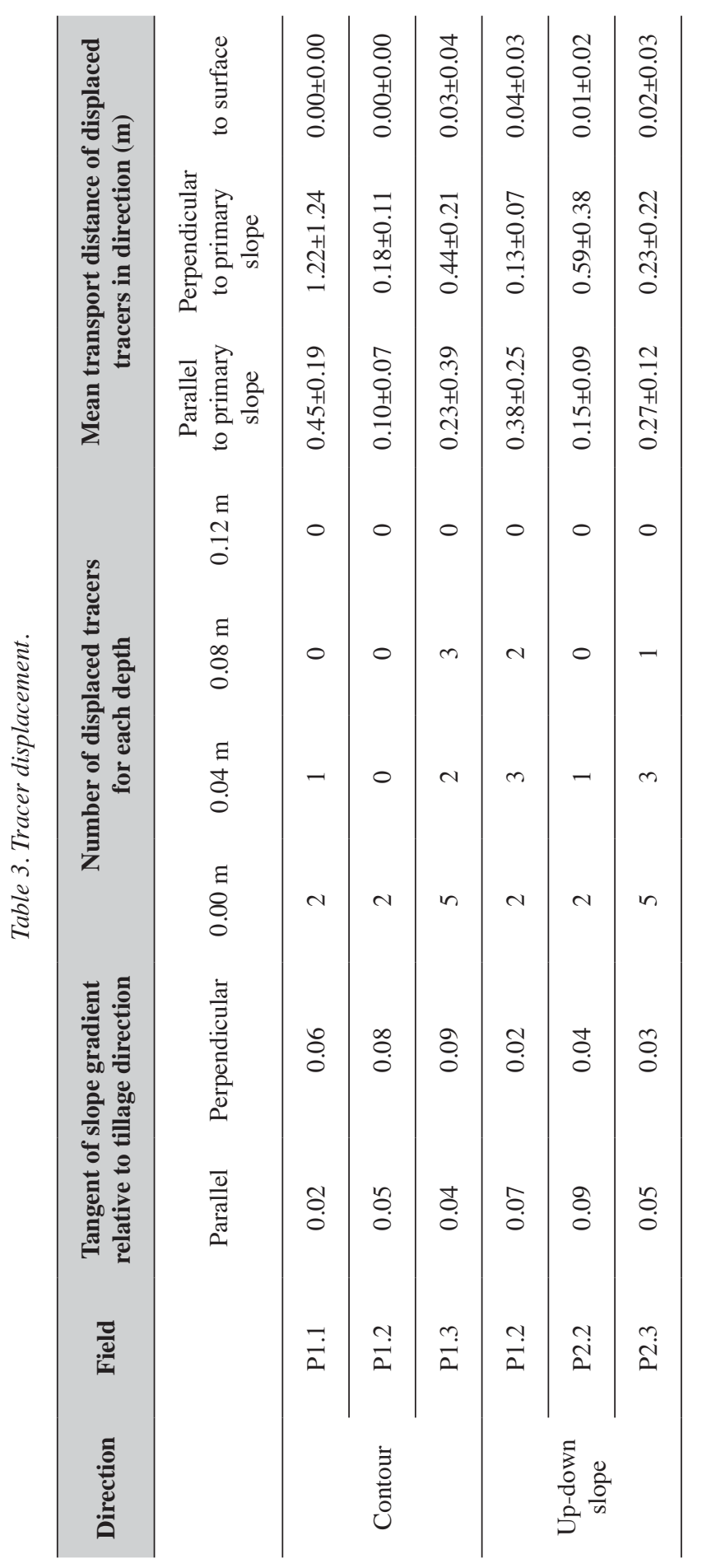


was found between the displacement and slope gradient (displacement $=0.6 *$ slope +6.5 ; $\mathrm{R}^{2}=0.00, \mathrm{p}<0.05$ ), even when both directions were considered separately. Most tracers moved along the main-slope direction and perpendicular to the primary slope (Fig. 4). During the contour tillage (tracer transects A-C in Fig. 4) the ard cut the soil at a depth of 0.1-0.12 m, exactly below the main root zone. The furrows were V- or U-shaped with mean surface widths of 0.05-0.1 m. The ard was caught on roots and subsequently released by the ploughman several times. This motion led to uplift and partial turnover of undercut soil (Fig. 5A). Similarly, the plough was released to the surface by the ploughman at the end of the furrow. Tracers only moved in transects where soil was in direct contact with the ard. If the ard was released, they were transported further in the air on longer distances (maximum $2.5 \mathrm{~m}$ ). Mean displacement parallel to the primary slope was $0.06 \pm 0.2 \mathrm{~m}$, while displacement perpendicular to the primary slope exhibited slightly higher variability $(0.06 \pm 0.3 \mathrm{~m})$. Mean displacement during contour tillage (perpendicular to primary slope) was towards the ridge (up-slope of tillage). At the convex-convex P1.1 plot (transect A), tracers were exclusively moved in the upslope direction of tillage. During tillage along to the primary slope (individual tracer displacement in transects D-F are plotted in Fig. 4), soil clods $\sim 0.20 \times 0.25 \times 0.10 \mathrm{~m}$ were broken and slightly turned or translocated over one another (Fig. 5B). The tracers moved within the furrows and with the clods of soil, where they were packed between dense roots. Along the primary slope, mean displacement was $0.03 \pm 0.19 \mathrm{~m}$, and $0.00 \pm 0.15 \mathrm{~m}$ perpendicular to the primary slope. Below the clods, the soil was loose and resembled a seedbed (Fig. 5C).

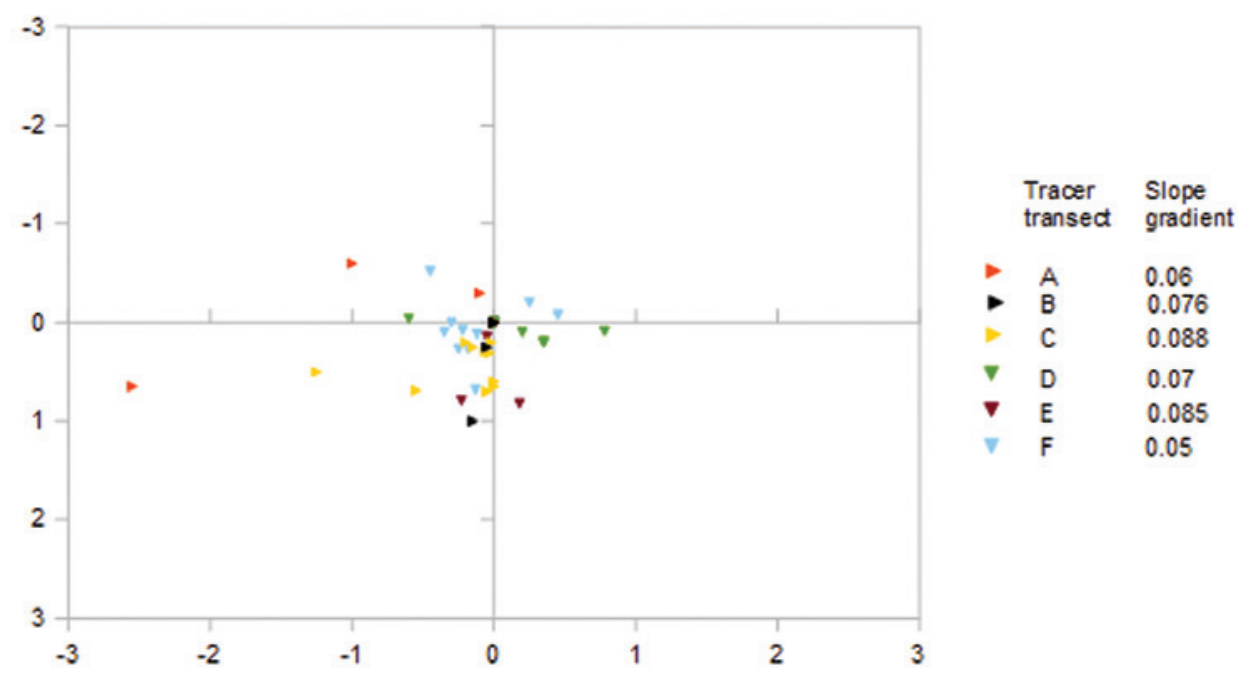

Figure 4. Tracer displacement (in meters) from original position [0,0] after each tillage pass, categorized according to slope gradient of individual tracer transects $(A-F)$ and tillage direction ( $\mathbf{\nabla}$ up-downslope, $\mathbf{c o n t o u r})$. Positive values indicate up-slope movement (towards the ridge), negative values downslope movement (towards the thalweg). 


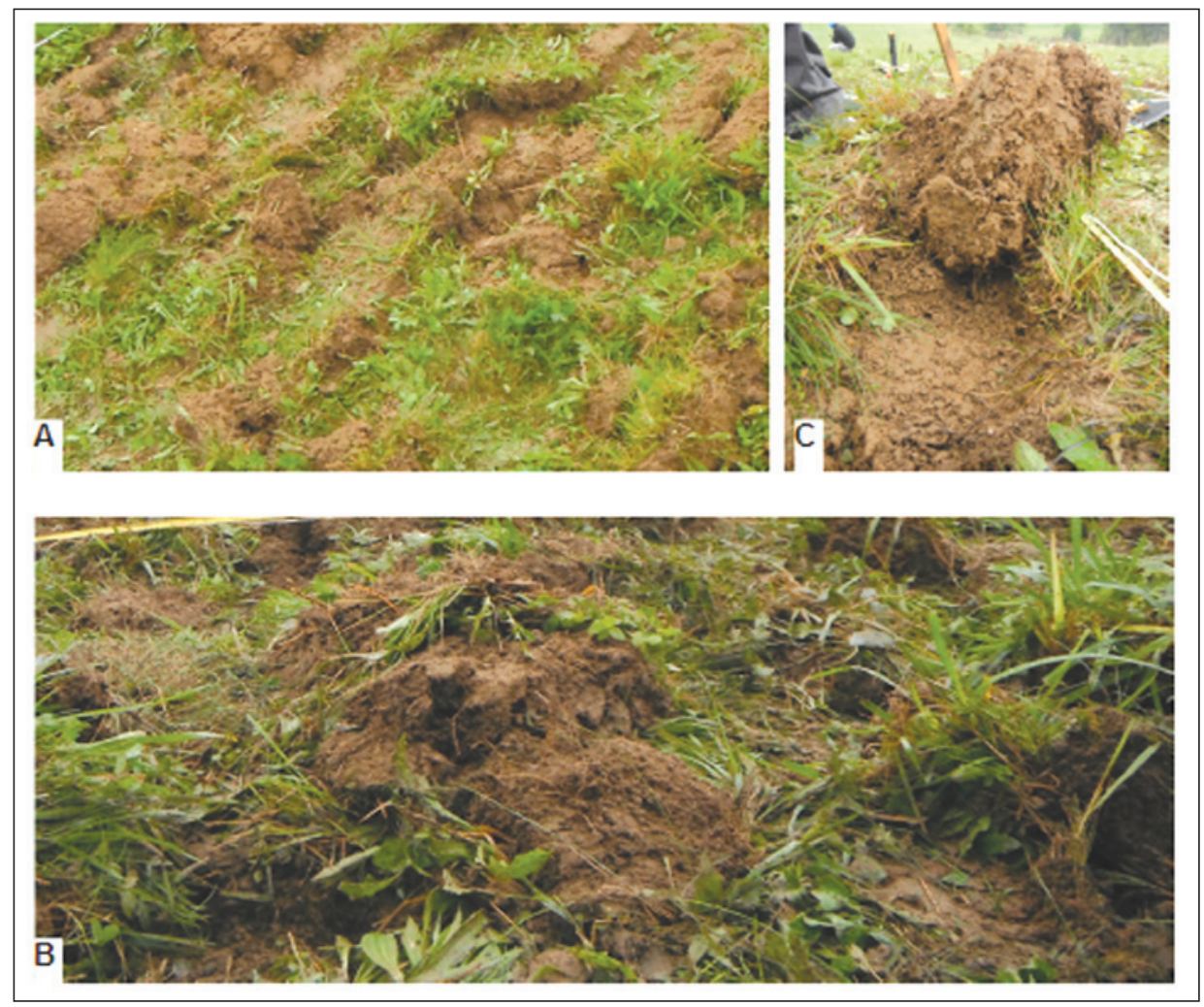

Figure 5. Soil surface after tillage. A: The first tillage approach (contour tillage) created rows of $V$ - or $U$-shaped troughs with a mean surface-width of 0.05-0.1 $\mathrm{m}$. The ard undercut the soil layer to a depth of $0.1 \mathrm{~m}$ and some of the soil was turned with the movement of the plough. $B$ : The second tillage operation (up-down slope tillage) subsequent to the contour tillage cut the soil clod with a mean size $\sim 0.2 \times 0.25 \times 0.1 \mathrm{~m}$, which were slightly shifted over each other or rotated. $C$ : A soil clod created by cross tillage (combination of the first and second operation) was cut under the main root zone. Below the clod was loose soil resembling the seedbed.

\section{Discussion}

4.1. Tillage erosion caused by wooden ard during the setting-up of a new field in grasslands

The results showed that the original ards found in the archaeological excavation could not be used for tillage. Ards B and C were capable of tillage, but the highest effectiveness and least issues in tilling grassland were observed for ard C, which was most similar to standardized sole ards from other experiments (Tegtmeier, 1993). For tilling grassland or a stubble field covered with low stems weeds (e.g., Setaria pumila or Medicago lupulina), common in Bronze Age-Iron Age (Kuna et al., 2012), the ard $\mathrm{C}$ was more suitable. Low soil bulk density and vegetation influenced soil transport and direction of tillage by increasing soil resistance, causing the ard to fall from rills, and increasing subsequent air-transport of tracers. 
On hillslopes with low inclination (2-8\%) measured mean transport distances were considerably lower than on slopes tilled by recent tillage tools (e.g., Van Muysen, 2002; De Alba et al., 2006; Van Oost et al., 2006; Li et al., 2007; Logsdon, 2013). The travel distances were shorter compared to those from traditional animal-drawn steel or metal ploughs and ards performed on steeper slopes (Dercon et al., 2007; Barneveld et al., 2009, Table 1). The translocation observed in this study was similar to Wildemeersch et al. (2014), who used an ox-drawn mouldboard steel pin plough along-contour and (consequently after a month) perpendicular to the primary slope direction on slopes of $4 \%$ and $16.5 \%$. Similar to our results, they observed long-distance tracer translocations, which were caused by transport on oxen hooves, but contrary to this study, they omitted translocation $>0.5 \mathrm{~m}$ in the tillage direction in calculations of mean displacement. During contour tillage, they did not observe net displacement in primary slope direction, whereas we found translocation $(0.06 \pm 0.2 \mathrm{~m})$ lower than travel distances as observed by Nyssen et al. (2000) and Dercon et al. (2007) on steep slopes. Results presented here indicate no significant relationships between slope and tillage translocation, which is similar to Wildemeersch et al. (2014), but contrary to other studies of traditional ards and ploughs (Thapa et al., 1999; Nyssen et al., 2000; Dercon et al., 2007; Barneveld et al., 2009). Transport distances differed in both directions, similar to the results of Dercon et al. (2007) and Heckart. (2006), who demonstrated that tillage direction influenced transport distances and that nonlinear relationships existed between slope/ profile curvature and soil translocation.

The high variability in tillage translocation was influenced by high surface roughness from grass stems hindering ploughing. Similarly, Semjonov (1974) concluded that vegetation decreased the speed of tillage. Additionally, dense roots increased resistance to ard penetration, and thus, reduced dissection of soil clods and their translocation. Wildemeersch et al. (2014) also found that hypogeal roots dragged a substantial amount of soil when pulled out by a mouldboard. Turkelboom et al. (1997) suggested that weed pressure in fields may affect tillage translocation. However, all previous studies (Table 1) were undertaken in permanent fields, and therefore further experiments with Bronze Age-Iron Age ards need to be performed with different management approaches (e.g., more similar to long-term ploughed field) in order to exclude the effects of vegetation.

\subsection{Ard tillage in seedbed preparation in a new field setup in grasslands}

Our tillage experiment confirmed that one-time repeated cross-tillage is not sufficient to prepare seedbed. Contour tillage produced furrows where seeds could be placed and covered by soil clods during the second tillage operation (perpendicular to the primary slope). However, seed displacement during the second operation was comparable to tracer displacement, and thus many seeds could be transported to the surface (instead of under it). Therefore, other methods of seedbed preparation should be considered prior and after the cross tillage. Prior to tillage, management could focus on the removal of above biomass and the destruction of roots by grazing or fire. Grazing may enable removal of grass (by cattle), bushes (by goats and sheep) and distortion of soil surface by root consumption (by pigs or animal hooves). If fire was applied, long 
time firing had to be used in order to destroy the roots of bushes or small trees (Lüning et al., 1980). Otherwise, fires could only cause removal of grass without affecting roots. This preparation may have eased effects of cross tillage, which separated larger soil clods below the root zone. Post tillage management could include (i) repeated cross tillage until soil clods were destroyed, (ii) destruction of soil clods by hoeing (e.g., Turkelboom et al. 1999; Zhang et al., 2004; Kimaro et al., 2005; Dupin et al., 2009), (iii) ploughing and harrowing (Wildemeersch et al., 2014) to prepare the seedbed for sowing. Complementary, seeding under clods (similar to recent conservation practices) may be preferred. However, the latter might be contradicted by the ability of crops (Triticum dicoccum) to compete with other grass species (Poaceae) for water and nutrients during the growing season. Previously, Hejcman et al. (2015) proved Triticum dicoccum outgrew other plant species in a field, but the experiment was not conducted in conditions such as those found here, where many different species of seeds and roots exist. Archaeological evidence confirmed repeated tillage in some fields (Verrill et al., 2010; Huisman et al., 2014) and the experiments with traditional ards in developing countries (e.g., Barneveld, 2009) showed that repeated tillage was a common management practice to destroy weeds. Therefore, it might be presumed the repeated tillage, or tillage and hoeing, can be effective measures to destroy the soil clods in order to prepare seedbed. If combined, they might increase low-intensity tillage transport.

\subsection{Contributions from an interdisciplinary approach to study tillage erosion}

Contrary to previous studies (Beranová, 1993), this interdisciplinary experiment combines technological aspects of tillage tool reproduction by testing physical labour methods of ploughing, plough management and its environmental effects due to tillage erosion. Evaluating tillage erosivity with this approach improved understanding tillage erosion under specific management conditions, as well as mandatory seedbed preparation and seeding prior to tilling. The results highlighted additional research questions regarding (i) management technology needed for set-up of new fields, (ii) stability of field systems in pre-historical landscapes, and (iii) tillage erosivity of each ard-type plough. Answers to such questions can provide parameters to aid some landscape evolution models (e.g., LAPSUS, WATEM-SEDEM ${ }^{\mathrm{LT}}$ ). Further exploration should include (iv) the actual intra- and inter-annual management of stable or fallowed field system and their economics, and (v) long-term environmental effect of tillage on soil fluxes, soil properties, biomass production and carbon release or sequestration in pre-historical landscapes using short- or medium-term experimental set-ups.

\section{Conclusions}

The following conclusions can be drawn from this interdisciplinary archaeologicalgeomorphological field approach to understand tillage erosion using prehistoric ards in a grassland and long-term fallow field:

i) The sole-ard plough was the most effective and caused the fewest issues by tillage in grassland. 
ii) Soil redistribution by tillage was hindered by vegetation cover. During the first tillage operation, only soil in direct contact with the ard moved, and was partially transported over large distances, primarily on convex slopes. During the second tillage operation, additional movement of soil clods occurred.

iii) Generally, down-slope movement prevailed during both tillage operations (contour and up-down slope), but transport distances were highly variable and mean displacement was much lower than previously measured values.

iv) Cross tillage of grasslands with an ard plough created soil clods and undercut the root system of grass species, but was not sufficiently for seedbed preparation.

\section{Acknowledgements}

The authors thank Jan Boček, Marek Komárek, Peter Krajčí, Michal Dientspier, Michal Hanšut, Ondřej Klápa, Petr Rataj, Jiř́ Skácelík and Ondřej Tomančák for their help with the experiment. Additional thanks to Mr. Jindřich Pavelka for providing the field plots. The financial support of Archaia Olomouc is acknowledged and appreciated. Anna Smetanová was supported by Marie-Curie FP7 COFUND People Programme, through the award of an AgreenSkills' fellowship (under grant agreement no. 267196).

\section{References}

Aberg, F.A., Bowen, H.C. 1960. Ploughing experiments with a reconstructed Donneruplund ard. Antiquity 34, 144-147.

Bac, S. 1928. Przyczynek do badań nad zmianą położenia ornych gruntów loessowych. Roczniki nauk rolniczych i lesnych 19 (1), 461-490.

Barneveld, R., Bruggeman, A., Sterk, G., Turkelboom, F. 2009. Comparison of two methods for quantification of tillage erosion rates in olive orchards of north-west Syria. Soil and Tillage Research 103, 105-112.

Beranová, M. 1993. Versuche zur vorgeschichtlichen und frühmittelalterlichen Landwirtschaft. Památky archeologické 84, 97-119.

De Alba, S., Borselli, L., Torri, D., Pellegrini, S., Bazzoffi, P. 2006. Assessment of tillage erosion by mouldboard plough in Tuscany (Italy). Soil and Tillage Research 85 (1-2), 123-142. http:// doi.org/10.1016/j.still.2004.12.002.

Brentjes, B. 1956. Der Schuhleistenkeil - Pflugschar oder Holzbearbeitungsgerät? Germania 34, 144-147.

Dercon, G., Govers, G., Poesen, J., Sánchez, H., Rombaut, K., Vandenbroeck, E., Loaiza, G., Deckers, J. 2007. Animal-powered tillage erosion assessment in the southern Andes region of Ecuador. Geomorphology 87 (1-2), 4-15. http://doi.org/10.1016/j.geomorph.2006.06.045.

Dotterweich, M. 2013. The history of human-induced soil erosion: Geomorphic legacies, early descriptions and research, and the development of soil conservation-A global synopsis. Geomorphology 201 (1), 1-34. http://doi.org/10.1016/j.geomorph.2013.07.021.

Dupin, B., De Rouw, A., Phantahvong, K. B., Valentin C. 2009. Assessment of tillage erosion rates on steep slopes in northern Laos. Soil and Tillage Research 103, 1, 119-126. http://doi. org/10.1016/j.still.2008.10.005.

Follain, S., Walter, C., Bonté, P., Marguerie, D., Lefevre, I. 2009. A-horizon dynamics in a historical hedged landscape. Geoderma 150 (3-4), 334-343. http://doi.org/10.1016/j. geoderma.2009.02.015. 
Glob, P. V. 1951. Ard og plov i Nordens Oldtid. Jysk Arkaeologisk Selskab, 24.

Govers, G., Vandaele, K., Desmet, P., Poesen, J., Bunte, K. 1994. The role of tillage in soil redistribution on hillslopes. European Journal of Soil Science 45, 469-478. http://doi. org/10.1111/j.1365-2389.1994.tb00532.x.

Graves, R. 1960. The Greek Myths. Volume 2, London, 412 p.

Hansen, H.O. 1969. Experimental ploughing with a Døstrup ard replica. Tools and Tillage 1 (2), 67-92.

Hejcman, M., Hejcmanová, P. 2015. Yield and nutritive value of grain, glumes and straw of Triticum dicoccum produced by prehistoric technology in comparison to T. aestivum produced by modern technology. Interdisciplinaria Archaeologica - Natural Sciences in Archaeology 6, 31-45.

Hennig, E. 1965. Bericht über die praktischen Versuche zur funktionellen Deutung der neolithischen Steingeräte. Archeologické rozhledy 17, 682-690 and 699-702.

Houben, P. 2012. Sediment budget for five millennia of tillage in the Rockenberg catchment (Wetterau loess basin, Germany). Quaternary Science Reviews 52, 12-23. http://doi. org/10.1016/j.quascirev.2012.07.011.

Houben, P. 2008. Scale linkage and contingency effects of field-scale and hillslope-scale controls of long-term soil erosion: Anthropogeomorphic sediment flux in agricultural loess watersheds of Southern Germany. Geomorphology 101 (1-2), 172-191. http://doi.org/10.1016/j. geomorph.2008.06.007.

Huisman, D.J., Raemaekers, D.C.M. 2014. Systematic cultivation of the Swifterbant wetlands (The Netherlands). Evidence from Neolithic tillage marks (c. 4300- 4000 cal. BC). Journal of Archaeological Science 49, 572-584. http://doi.org/10.1016/j.jas.2014.05.018.

IUSS Working Group WRB. 2015. World Reference Base for Soil Resources 2014, update 2015 International soil classification system for naming soils and creating legends for soil maps. World Soil Resources Reports No. 106. FAO, Rome.

Kănčev, K. 1956. Zemledeleski orădija ot neolita i neolita v bălgarskite zemi. Archeologia (Sofia) 9 (3), 50-64.

Kimaro, D.N., Deckers, J.A., Poesen, J., Kilasara, M, Msanya, B.M. 2005. Short and medium term assessment of tillage erosion in the Uluguru Mountains, Tanzania. Soil and Tillage Research 81, 97-108. http://doi.org/10.1016/j.still.2004.05.006.

Kosmas, C., Gerontidis, S., Marathianou, M., Detsis, B, Zafiriou, T., Van Muysen,W., Govers, G., Quine, T., Van Oost, K. 2001. The effects of tillage displaced soil on soil properties and wheat biomass. Soil and Tillage Research 58 (1-2), 31-44. http://doi.org/10.1016/S01671987(00)00175-6.

Kováčik, P., Veselá, P. 2010. ARO 000/2009 - Opava - “Obchodní a společenské centrum Breda\&Weinstein”. In P. Kováčik, P. Veselá (eds.), Výroční zpráva za rok 2009 Archaia Olomouc o.p.s., Olomouc, 7.

Kuna, M., Němcová, A., Gentizon Haller, A.L., Haller, M., Hanykýř, V., Kloužková, A., Kočár, P., Kovačiková, L., Malyková, D., Mazač, Z., Slabina, M., Tempír, Z., Vařeka, P., Vlčková, Z., Zemanová, P. 2012. The evidence of settlement discard. Finds from the Final Bronze Age at Roztoky and the depositional analysis of archaeological context. Prague, $358 \mathrm{pp}$.

Lemmen, C., Gronenborn, D., Wirtz, K.W. 2011. A simulation of the Neolithic transition in Western Eurasia. Journal of Archaeological Science 38 (12), 3459-3470. http://doi. org/10.1016/j.jas.2011.08.008.

Lerche, G. 1986. Ridged fields and profiles of plough-furrows. Ploughing practices in Medieval and post-medieval times. A study in experimental archaeology. Tools and Tillage 5 (3), 131156.

Lerche, G. 1991. Wear marks produced in plough-furrows and on front of mouldboards. Conclusion based on experiments with replicas of a medieval plough. Archéologie expérimental 2, 218-222. 
Lerche, G. 1994. Ploughing implements and tillage practices in Denmark from the Viking Period to about 1800: experimentally substantiated. Herning, $321 \mathrm{pp}$.

Lerche, G. 2014. An experimental approach to medieval cultivation: The Danish wheel plough and tillage practice, Exploring and Explaining Diversity in Agricultural Technology 2, 46-57.

Li, S., Lobb, D.A., Lindstrom, M.J. 2007. Tillage translocation and tillage erosion in cereal-based production in Manitoba, Canada. Soil and Tillage Research 94 (1), 164-182. http://doi. org/10.1016/j.still.2006.07.019.

Lindstrom, M.J., Nelson, W.W., Schumachter, T.E. 1992. Quantifying tillage-erosion rates due to moldboard plowing. Soil and Tillage Research 24, 243-255. http://doi.org/10.1016/01671987(92)90090-X.

Lobb, D.A., Kachanoski, R.G., Miller, M.H. 1999. Tillage translocation and tillage erosion in the complex upland landscapes in south-western Ontario, Canada. Soil and Tillage Reasearch 51, 189-209. http://doi.org/10.1016/S0167-1987(99)00037-9.

Logsdon, S.D. 2013. Depth dependence of chisel plow tillage erosion. Soil and Tillage Research 128, 119-124. http://doi.org/10.1016/j.still.2012.06.014.

Lüning, J., Meuerees-Balke, J. 1980. Experimenteller Getreideanbau im Hambacher Forst, Gemeinde Elsdorf, Kr. Bergheim/Rheinland. Bonner Jahrbücher 180, 305-344.

Nyssen, J., Poesen, J., Haile, M., Moeyersons, J., Deckers, J. 2000. Tillage erosion on slopes with soil conservation structures in the Ethiopian highlands. Soil and Tillage Research 57, 115-127.

Nyssen, J., Debever, M., Poesen, J., Deckers, J. 2014. Lynchets in eastern Belgium-a geomorphic feature resulting from non-mechanised crop farming. Catena 121, 164-175. http://doi. org/10.1016/j.catena.2014.05.011.

Podborský, V. 1984. Zpráva o počáteční fázi některých experimentu na neolitické lokalitě v Tešeticích - Kyjovicích. Sborník prací Filozofické fakulty brněnské univerzity:řada E archeologicko-klasická 33, 225-226.

Quente, P. 1914. Steinzeitliche Ackerbaugeräte aus der Ostprignitz, Erdhacken und Pflüge, und ihre Schaftungsmöglichkeit. Prähistorische Zeitschrift 6, 180-187.

Reynolds, P.J. 1979. Iron-Age Farm: The Butser Experiment. London, 108 pp.

Reynolds, P.J. 1988. Ploughs in Prehistory. British Archaeology Magazine 7, 5-7.

Semjonov, S.A. 1974. Proischoždenije zemledelja. Leningrad, 226 pp.

Smetanová, A., Verstraeten, G., Nyens, G., Notebaert, B., Szwarczewski, P., Čurlík, J., Burian, L., Kazeminejad, S.A., Létal, A., Dotterweich, M. 2015. The influence of landscape design on soil erosion in the Chernozem region of the South-West Foreland of the West Carpathians in the Medieval to Modern Times and po-collectivization periods. EGU General Assembly Conference Abstracts, 17, 14121.

Šach, F. 1966. Museum experimenting as a testing method of the productivity of labour in the past. Acta Museorum Agriculturae, 37-41.

Tegtmeier, U. 1993. Neolithische und bronzezeitliche Pflugspuren in Norddeutschland und den Niederlanden. Archäologische Berichte 3, 1-143.

Thapa, B.B., Cassel, D.K., Garrity, D.P. 1999. Assessment of tillage erosion rates on steepland Oxisols in the humid tropics using granite rocks. Soil and Tillage Research 51 (3-4), 233-243. http://doi.org/10.1016/S0167-1987(99)00040-9

Turkelboom, F., Poesen, J., Ohler, I., Ongprasert, S. 1999. Reassessment of tillage erosion rates by manual tillage on steep slopes in northern Thailand. Soil and Tillage Research 51, 245-259. http://doi.org/10.1016/S0167-1987(99)00041-0.

Turkelboom, F., Poesen, J., Ohler, I., Van Keer, K., Ongprasert, S., Vlassak, K. 1997. Assessment of tillage erosion rates on steep slopes in northern Thailand. Catena 29 (1), 29-44. http://doi. org/10.1016/S0341-8162(96)00063-X. 
Van Muysen, W., Govers, G., Van Oost, K. 2002. Identification of important factors in the process of tillage erosion: the case of mouldboard tillage. Soil and Tillage Research 65 (1), 77-93. http://doi.org/10.1016/S0167-1987(01)00282-3.

Van Oost, K., Van Muysen, W., Govers, G., Deckers, J., Quine, T.A. 2005. From water to tillage erosion dominated landform evolution. Geomorphology 72, 193-203. http://doi.org/10.1016/j. geomorph.2005.05.010.

Van Oost, K., Govers, G., de Alba, S., Quine, T.A. 2006. Tillage erosion: a review of controlling factors and implications for soil quality. Progress in Physical Geography 30, 4, 443-466.

Van Oost, K., Verstraeten, G., Doetterl, S., Notebaert, B., Wiaux, F., Broothaerts, N., Six, J. 2012. Legacy of human-induced C erosion and burial on soil-atmosphere C exchange. PNAS 109, 19492-19497. http://doi.org/10.1073/pnas.1211162109.

Verril, L., Tipping, R. 2010. A palynological and geoarchaeological investigation into Bronze Age farming at Belderg Beg, Co. Mayo, Ireland. Journal of Archaeological Science 37 (6), 1214-1225.

Wildemeersch, J.C.J., Vermang, J., Cornelis, W.M., Diaz, J., Gabriels, D., Ruiz, M.E. 2014. Tillage erosion and controlling factors in traditional farming systems in Pinar del Río, Cuba. Catena 121, 344-353. http://doi.org/10.1016/j.catena.2014.05.027.

Zhang, J.H., Lobb, D.A., Li, Y., Liu, G.C. 2004. Assessment of tillage translocation and tillage erosion by hoeing on the steep land in hilly areas of Sichuan, China. Soil and Tillage Research 75, 99-107. http://doi.org/10.1016/j.still.2003.08.003. 